\title{
Islamization of Nigeria: Implications for Sustainable Peace
}

\author{
Christian O. Ele
}

General Studies Division, Enugu State University of Science and Technology, Agbani, Enugu State, Nigeria

\begin{abstract}
This paper discusses Islamization of Nigeria and its implications for sustainable peace. Islamization agenda means the articulated methods which Muslims softly or subtly apply to win new members or the programs they aggressively or violently follow in order to conquer or coerce people into the Islamic faith. Missionary enterprise such as Islamization is not a strange phenomenon in all religions. This is because each one makes some efforts to get new converts. In fact, it is a proper and natural activity which characterizes all faiths. Therefore Islamization, Christianization or traditional-religionization shows the noble characteristic inherent in these religions. Nigeria has religious pluralism as one critical expression of her diversity. Christianity, African Traditional Religion and Islam are the three major religions in the country. When the multiplicity of faiths found to exist simultaneously within a place celebrates inclusivity, it shows the beauty of her strength. But if on the contrary, it takes on the features of intolerance, then the necessary consequence becomes religious terrorism. The findings of this paper reveal, among other things, that Islam has multi-dimensional approaches to ensuring that Nigeria becomes an Islamic state. Islamization is a conscious and pious fulfillment of Islamic obligations. It also discovered with some rude shocks that Islam identifies every non-muslim as an infidel who is good only to be wasted by torture and gruesome death. This means that peace is compromised variously in the enterprise of Islamization. The methodology employed in this work is historicdescriptive which means that the schemes of Islamization were carefully studied and interpreted using the multi-variant peace values as frames of reference.
\end{abstract}

Keywords: Islamization, Nigeria, Implications, Sustainability and peace.

\section{Introduction}

There is a historical interpretation of the interactions as a web of actions and reactions within the religious space of Nigeria. One observes a constant struggle as to which religion takes the soul of the religious space of Nigeria. Is it Islam through its Islamization agenda or is it Christianity with its evangelization or missionary mandate? And in recent times, even the practitioners of indigenous religion have also expressed some concerns with her values as the authentic cherished types from antiquity which should govern the religious space of Nigeria. The other aforecited two, the Abrahamic monotheistic faiths, are regarded as foreign and intruders by the adherents of the third, the folk religion. In other words, it tries to traditional-religionize Nigeria, so to speak. The practitioners want the traditional religious feasts and calendar to be nationalized and given public holidays. Some of their grooves and shrines are even projected as tourist centers.

Nigeria is a secular nation-state. She has a constitution which promotes her national values that are not tied to religion in the absolute sense. The wisdom behind this secularity took conscious cognizance of the facts that Nigeria is a country of diversities in her multi-ethnic, multi-religious and multi-cultural realities to mention but three and therefore its philosophy is to put balances which depict neutrality, objectivity, and equity so that the multiplicity of faiths found within her space would thrive naturally and enjoy their respective freedoms.

Religious pluralism presents a variety of religious experiences and spices in religious adherence that function choices. According to Ele (2015) "Religious pluralism implies a diverse variety and multiplicity of faiths found to exist simultaneously in a given society. The beauty of these religions in their respective distinctiveness, even as they uphold and teach variegated divine sparks of the incomprehensible Supreme Being (God) is seen when they inclusively work together in one purposeful and concerted effort to unfold (de-envelope) the naturalness which humanity must conquer in order to be termed "developed". He maintains that within the contexts of multi-faceted socio-cultural backgrounds of ethnicity, secularized orientations and de-secularization, empirical scientific influences, atheistic bents and humanism, divergent political affiliations, philanthropy and economic visions, one finds religion shaping the history of humanity in the positive sense. However, the competing conceptions of One and Many in Metaphysics are seen as well in the Religious pluralism of one God, many religions, and one religion, many denominations, and sects. The epistemological validity of Truth as One is challenged by the veracity and illusions of inclusive-exclusive standpoints which religions present in the conflicting perceptions of one reality (Ele, 2017). In other words, “... its plurality can become an ugly weakness which functions the sundry vices of 
absolutism, intolerance, violence, bigotry to mention but these which reveal the destructive, divisive and dark sides of religion (Ele, 2015). In the face of religious intolerance, one sees gestures of pride and dominance, platforms of suppression, and expressions of superiority complex from different faiths at different times in the world. Along with this view, Ele (2001) wrote that "The history of Christianity in Nigeria today is replete with dramatic chapters of the massacres of Christ's faithful by fanatical Muslims. Too many a Christian, especially in the Northern part of the country have paid the tribute of blood while others are still under the yoke of persecution, the absence of religious freedom, shackles of violence and the threat of death. Some Christian sacred spaces have been committed to smoking ruins at any sudden eruption and the least provocation of ethnic/religious quarrel". In Nigeria today, especially with the current dispensation of civil governance, there have been voices raised from different quarters that Islamization agenda have been excavated from its grave of inattention, resuscitated and renewed with much vigour. In support of this view, Isiguzo (2016) wrote that the renowned constitutional lawyer, Prof. Ben Nwabueze said: “Islamization agenda is real, it's not something that somebody has just conjured up, it's there. And it's been implemented gradually”.

This paper discusses Islamization of Nigeria and its Implications for Sustainable Peace. One asks, what does peace mean in the context of religious intolerance such as the perceived Islamization agenda and dispositions for an Islamic theocracy in Nigeria? Again, what does peace yield in the milieux of religious inclusivity, ecumenical dialogue, and freedom? It is an indubitable fact that every religion makes a demand of its followers to win more converts. Each religion advertises, by way of thorough missionizing, her values packaged to appeal to the target audience to be converted or to neophytes. However, as some religions appeal and persuade, others force and coerce. The use of force or the appeal for choice is all implicated in the perceptions of what conversion means at the instance of every religion.

The Islamization and comprehensive annihilation of Christian presence in an otherwise heterogeneous, pluralistic, secular socio-political Nigeria is understood by Christians in the country to be certain, subtle and steady.

In the next subsection, we shall go into the historical excursus of those actions that make people think that the Islamization of Nigeria is progressively active.

\section{Historical Excursus of Islamization Agenda}

The Islamization agenda in post-independence Nigeria is linked with the personality and strategy of Sir Ahmadu Bello, the Sarduana of Sokoto. His mission and vision were to win Nigeria and indeed the whole of the African continent to Islam; a game to which he was totally committed. Onotu (1988) captured the Sarduana's words thus: "I have earlier spoken of conversion of non-muslims to Islam. I would like to say that this is only a beginning as there are other areas we have not yet tapped. I hope when we claim Nigeria, we will go further afield in Africa”. Ahmadu Bello had died long ago yet "For the followers of Islam, his course must be consistently and vigorously pursued to the very end even if it needs precipitating this country into an endless religious conflict to achieve that purpose" (Onotu, 1988). It is good to understand the Islamic perceptions of the relationship between Faith and politics. A Muslim does not differentiate between his faith and politics while in political or any public office. To buttress this fact, Banu az-Zubair (n.d) wrote that "the basis of the state, for the Muslim, is ideological, not political, territorial, or ethical, and the primary purpose of the state is to defend and protect the Faith, not the State". Therefore, while the Christian is saying, there is a need to separate Faith from the state, politics from religion and to acknowledge caesaropapism as a political theory with deficits, the Muslim takes both as one. He, based on this understanding, uses the machinery of government and the economy of the state to advance his religion. This neutralization or breach of the constitution to ensure favouritism for Islam against other religions is a sin against social justice. The Christian permeates the secular arena such as politics, culture, education, science and technology, economy, et cetera with the values of the gospel.

(Ele, 2001) sees the multi-dimensional approaches of Islamization in the following areas:

\subsection{Organization of Islamic Cooperation (OIC) and Sundry Islamic Organizations}

Nigeria is a secular state where state religion is prohibited and freedom of religion guaranteed (cf section 10, 38 (1) Constitution of the Federal Republic of Nigeria). But early 1986, the federal government secretly sent representatives to Fez, Morocco, and Nigeria was enrolled as the forty-sixth member of the Organization of Islamic Conference (OIC). On 28 June 2011, it changed its name to Organization of Islamic Cooperation. Nigeria is still a member. As Onotu (1988) succinctly observed:

The OIC crisis is the crowning point of the historical and overall attempt to Islamize

Nigeria. The attempts that dated back from the Sokoto Jihad of the 19th Century that was led by the Islamic reformer and crusader, the Uthman Dan Fodio cutting through the period of Sarduana of Sokoto ... down through Shagari and the (IBB) present administration of the country. One then can see a consistent attempt to accomplish this long-standing Islamic objective.

On November 28, 1989, in Abuja Nigeria, The Islam in Africa Organization (IAO), an initiative of the African countries of the OIC, was founded. In 1991, the statutes and objectives of IAO were ratified and this means its official definitive inauguration. With this, its first communiqué known as Abuja Declaration was made public. The chief motive is to Islamize the whole of Africa through these means:

- "To ensure only Muslims are elected into all political posts of member nations".

- "To eradicate in all its forms and ramifications all non-muslim religions in member nations (such religions shall include Christianity, Ahmadiyya and other tribal modes of worship unacceptable to Muslim)" (the word Christianity is underlined in the declaration).

- "To ensure the ultimate replacement of all western forms of legal and judicial systems with the Sharia in all member nations before the next Islam in Africa conference". 
- "To ensure the appointment of only Muslims into strategic national and international posts of member nations" (Damilolly, 2014).

The implementations of the above declarations are with us here in Nigeria with vivid certainty. According to the Charter of OIC, the first objective is "to promote Islamic solidarity among member states". But, Nigeria is a secular state. Therefore her OIC membership contradicts her constitution. In the face of this confusion and rape of justice, the Catholic Bishops Conference of Nigeria CBCN (2001) offered withdrawal as the solution in the following words:

We urge withdrawal because we have carefully examined the arguments put forward in favour of continued membership - religious, economic, political, diplomatic etc, and we find them all unconvincing. On the contrary, we raise one fundamental objection to Nigeria's entry into the OIC. With its religious pluralism, Nigeria cannot as a state become a member of an international body whose objectives are essentially the promotion of one particular religion. To do that would mean injustice to other religions and to their adherents. This injustice in an area so all-embracing and sensitive as religion is bound to manifest itself also in other areas of national life, political, economic, social, cultural, legal, etc.

On October 20, 2017, President Muhammadu Buhari was in Istanbul, Turkey to attend the 9th summit of D 8 which comprises of Egypt, Indonesia, Bangladesh, Malaysia, Pakistan, Iran, and Turkey. The members of the Developing - 8 suppose to be all Muslim countries. Nigeria is the odd country in their midst because she is not an Islamic country. Earlier in 2016, President Buhari indicated interest to join a $34-$ member Islamic Military Alliance Against Terrorism (ISMAT) to give a false indication that Nigeria is an Islamic country. ISMAT has all membership as Muslim countries. ISMAT implication for Nigeria means taking sides with Sunni tradition, a denomination of Islam and then being at logger's heads with another denomination, the Shiites (Nnanna, 2016; Premium Times, 2016).

Islamic Banking through her Sukuk (Islamic bonds) which has no riba (interest) was embraced by some Nigerians without knowing its full implications in Islamization. Some state governments, especially of the Christian, dominated population took the sukuk because there is no riba. However, the reciprocity for such a kind gesture could be to build mosques and give Islam a vivid presence in their states. Reacting to Nigerian's misgivings on sukuk, the Vice President, Osibanjo (2017) said, "there were no plans to Islamize Nigeria through sukuk bond or the country's membership in Islamic Development Bank. Nigeria is the fourth largest shareholder in the Islamic Bank". The response is in same style with that of Buhari, his Boss who says "no one will Islamize Nigeria", when it is evident that everything is on the contrary.

\subsection{Political Jihad}

It is an understatement to write that the level of Islamization agenda linked with Nigerian politics is variegated and voluminous. According to Eyoboka and Akinrefon (2017). The National Christian Elders Forum (NCEF), a group which comprises of different professionals and former senior army generals such as the former Defense Minister, Theophilus Danjuma, has insisted that that Federal Government of Nigeria was planning to Islamize Nigeria through Jihad. The Forum maintains that Islamists have been interfering in the governance of Nigeria using Taqiyya (approved deception) as stealth/civilization Jihad while Boko Haram and Fulani Herdsmen as violent Jihad were more aggressive in their objective of destroying democracy in the country. The aim of this political Jihad is to remove democracy as a national ideology and entrench Sharia ideology as source of legislation for Nigeria. Political Jihad comes from many dimensions such as:

(1) Shariazation of Nigeria: As Ele (2001) wrote: To Islamize Nigeria, fanatical Muslims have demanded that the Sharia law is entrenched in the constitution of the Federal Republic of Nigeria. As it proved impossible to do that within today's frame of history, some Northern states went ahead and adopted Sharia as their state's law. CBCN (2001) warns: "We are particularly concerned about the persistence of Sharia-related politics in the country. The adoption of the Sharia law by some states in Nigeria has continued to create a situation of unrest in which people are killed and maimed and thousands of others are displaced from their homes and places of work. We warn that it is too costly to create a situation in which the destiny of this nation is left in the hands of fanatics, be they religious or political". In his article: "Sharia and the Arab Hypocrisy", Eze (2001) argued that if the Lebanese could not be moved by the ignoble activities of thousands of harlots in Beirut, if the council of Mullahs in Saudi Arabia was untouched by the high rate of armed robbery, drunkenness, and prostitution obtainable both in Riyad and Medina; if Hosni Mubarak's Shibanis could continue to tolerate the sale of Alcohol within a two hundred meters radius of the oldest and most respected Islamic institution of higher learning, Al Azrah University and if Gadaffi is yet to be moved by the menace of gamblers in the streets of Sharia Zawiya in Tripoli, nothing but misguided zeal would explain the recent craze for the Sharia code in some states in the North. It is pathetic that while Muslims in Mali, Chad, Niger, Nigeria, and Somali, who have no trace of Mohammed's blood in their system, are forced to adopt Sharia, the sons of Mohammed (The Arabs) are spared this cumbersome and anachronistic legal observance. The scions of Uthman Dan Fodio should in the interest of their overwhelming ignorant followers whose lot has not been enviable, retrace their steps towards shariazation. In the same vein, Prof. Idris Salem, an Islamic theologian said: "The Egyptians have discovered that Sharia does not place food on their tables, hence their non-adherence to the letters of the code" (cited by Ele (2001)). Sharia ideology is linked with Islamization through:

i. Aggressive hatred of Christians that has led to ethnoreligious riots especially in the North that has left hundreds of churches burnt and thousands of Christian dead.

ii. The refusal to rebuild churches that were burnt down in every instance of provocation, which was not real but only imaginary.

iii. The bokoharamization militancy and terrorism. History has it on good notes that "In 1804 - 1808, Fulani came in from Guinea to the Northern part of Nigeria, led by Usman Dan Fodio. He led in 
jihad against the Hausa Kingdoms of Northern Nigeria. The forces of Usman Dan Fodio slowly took over more and more of the Hausa Kingdoms through war. By 1810, Fulanis had already conquered all Hausas. They formed Boko Haram sect solely for the process, waiting for Buhari or any of their Fulani brothers to come in power.... Now their dream has been achieved having their brother on top (hopefornigeriaonline.com, 2017). It is evident that bokoharamization of Nigerian politics contributed its own measure in the outcome of the 2015 presidential general elections that saw Dr. Goodluck Ebele Jonathan, a Southern Christian concede defeat to General Muhammadu, a Northern Muslim. The Boko Haram leader in 2012 in one of his videos gave the religious undertone of their Jihad thus: "It is between Muslims and Unbelievers (arna). It will stop when Islamic religion is the determinant in governance in Nigeria or, in the alternative, when all fighters are annihilated and no one is left to continue the fight (Eyoboka and Akinrefon, 2017). He warned that any Muslim who helps an unbeliever in this war is an unbeliever and therefore would be butchered like an unbeliever.

iv. The Fulani Herdsmen are not just persons engaged in animal husbandry or cattle rearing. They are, very importantly, Islamic missionaries meant to achieve a comprehensive occupation of all Nigerian geo-space. In order to achieve this, the Grazing reserve bill which if mistakenly passed would give the Fulani tribe places mapped out for them in all the 36 states of Nigeria. This means more Fulani population in all the states, more mosques and more knowledge of all the terrains for aggressive Jihad. In this wake, the local inhabitants would either accept the Koran or take the sword - all is Islamization. When this bill failed to sail through, they introduced Cattle Colonies. Cattle Colony is a brand of Jihad in order to expedite action on Islamization Agenda. This has ugly consequences as the grazing bill. On this note (Jannah, 2018) reported that the Catholic Bishops of Lagos Ecclesiastical Province condemn the Cattle Colonies in their Magisterium thus: “... we reject the proposed move by the Federal Government to establish Cattle Colonies across the various states of the Federation as a way of finding a lasting solution to the herdsmen/farmers clashes. Such a move is not only capable of exacerbating an already tensed atmosphere, but also leave one with the impression that the much-touted Islamization agenda of Nigeria is an ongoing project that may have tacitly received the approval of Mr. President". In 2017, the Fulani herdsmen unleashed deadly attacks in Enugu, Adamawa, Taraba, Benue States and on the citizens of Southern Kaduna that left scores dead. All we hear from the government are "there should be no reprisal attacks", "we have set up panels of inquiries" and "we are on top of the situation", yet concrete actions to bring about justice are absent and thus incentives for peace are not harnessed.

v. There is Mass Migration to the South. The Islamization of Nigeria includes too the phenomenon of the co-ordinated exodus of young Muslims from the North into Southern Nigeria. These young people engage in menial jobs, petty trading, low profile transportation activities such as Keke Napep and Okada riding, repairing pots and footwears, suya selling, shoe-polishing, hawking on tiger nuts, kola nuts and dates, wrist watches, belt, clothes, sugar cane, traditional medicine and serving as watch/gate men, et cetera. Everybody knows that they outnumber their customers; for instance, 10 of them who are cobblers can pass in one street within 5 minutes. Therefore their sustenance cannot be from their respective economic activities, they are maintained by their Islamic faith, religious lords, and bigots who support them richly and variously.

With this familiarization of all the hooks and crannies of the hitherto strange communities, it becomes easy to conquer the local, indigenous population. On a large scale, Fulani/Islamic migrants enter Nigeria illegally due to its porous borders. These are not Nigerians but those who are imported or on their own come to nationalize for the sake of Islamization project. It is the culture of Fulani people to hail from wherever they settle unlike the Igbo people and other tribes who must go back, alive or dead, to their ancestral locations. This is part of the game in the citizenship/indigeneship debate in the country. Their indigeneship everywhere means Islam everywhere.

vi. The Bias of the Nigerian Constitution. The foundation of Islamization of Nigeria is laid in the Nigerian constitution that recognizes only Islam. According to Damilolly (2014). Bishop Joseph Bagobiri (Kafanchan Diocese) and Pastor Emmanuel Bosun (Ogun State), the Christian delegates who represented Christian leaders in the constitutional amendment conference detailed the imbalances in the Nigerian constitution. Both observed that the 1999 constitution of the Federal Republic of Nigeria mentioned Sharia 73 times, Grand Khadi 54 times, Islam 28 times, Muslims 10 times and there is no single mention of Christ, Christian, Christianity or Church. These gaps and culpable bias in the Constitution were calculated and crafty kept in place with the aims of Islamization and to give the mischievous impression that Nigeria is an Islamic Country.

vii. Education: After the Nigeria - Biafra civil war, Muslim scholars like Professors Babs Fafunwa craftly influenced and maneuvered the Gowon administration to take over schools from Christian missionaries. He sailed through with the false ideology to produce "secular and citizenship-oriented Nigerians" but that was a sinister plan to stop the Gospel enterprise through the schools. Names of Christian schools were changed to Muslim names: St. John's College, Kaduna (Catholic) became Rimi College, Kaduna; Baptist Teacher's College, Minna became Ahmadu Bahago College (named after the Emir of Bida); Queen of Apostles' College, Kaduna became Queen Amina College (named after the 16th Century Queen of Zaria who was a Muslim (Onotu, 1988). Christian students found it difficult to practice their faith in these Muslim denominated and oriented schools. These Islamic manipulations were to clamp down Christian evangelism. As lands were denied Christians for the building of schools and churches, Muslims embarked on the large-scale training of missionaries and were also establishing Quaranic and Islamic schools, building mosques in strategies places thus enhancing their mission of Islamization. 
Even today, traces of Islamic plan to destroy the religious psyche of our young Christians in Tertiary schools are on record. In some Federal Universities even in the Christian dominated Eastern part of the country, lectures and examinations could be held on Sundays (Ele, 2001). In some other places, Christian fellowships are banned in schools in order to promote Muslim associations. Hijab is made part of the uniform in some schools while Christian outfits are banned. The recent attempts on the school curriculum to devalue Christian Religion Studies are evidence of the Islamization process.

viii. Other Methods: Other methods of Islamization include: (i) Weapons of psychological war such as dominating the social media with the false story of Nigeria as an Islamic country. There is potent false propaganda in the social media that Nigeria is an Islamic country. This is totally false. Another content of the miseducation is that Muslims are more in population in Nigeria. This is also untrue. The North is described as the Muslim North. This is not the solution as Christians largely populate the North. All these are false propaganda to miseducate the world in order to term Nigeria an Islamic state. (ii). Weapons of physical war of conquests of communities with either Koran or sword. The dominance of local inhabitants by militancy and installing of emirs (iii). The kidnapping of religious persons such as the clergy, (iv). Abuse of women and girls by rape thereby ridiculing the cherished cultural values of the people. (v). Marriages with the girls and women of their host communities or Christian Youth Corpers meant to serve in the North. (vi). Abduction and abuse of traditional rulers and respected persons in towns and villages. (vii). the Islamic symbols found on the plates, spoons, shirts, forks and our national currency called Ajami in Arabic. (viii). The motto of the Nigerian Army written in Arabic and translated into English - "Victory comes from God". (ix). The banning of prayers in primary/secondary schools during the Assembly and dismissal. (x). The building of government infrastructures such as the Presidential Villa, Abuja with Islamic Architectural designs. (xi). Sudden nocturnal attacks on the unsuspecting communities, (xii) Northernization of Nigeria's security outfit. (xiii). Stopping of Christian preachings and gatherings such as crusades and early morning cries, periods, et cetera.

In the face of these difficulties on the account of their faith, the Christians maintain the values of Jesus Christ which, inter alia, include:

1. Respect your leaders and take them as appointed by God (Romans 13:1-7).

2. Turn the other cheek (Matthew 5:38-40).

3. Your neighbor is anybody, not just the person connected with you by consanguinity or affinity (Luke 10:25-37).

4. The golden rule: As you would like others to do to you, do so to them (Luke 6:31).

5. Love your enemies and pray for those who persecute you (Matthew 5:44).

6. All authority in heaven and on earth has been given to me, therefore go and preach (Matthew 28:17-20; Mark 16:15; Matthew 10:1ff; Luke 10:1ff). In Christian Religion, authority was given to us. Christian preachers go without sandals, no food, no bag, no shirts or staff not to talk about going on a mission with bombs, swords, and guns as one can see in corrosive jihadism across continents and whose currency are found too in Nigeria.

7. In John 18:11 and Mathew 26:52, Jesus told Peter to put back his sword. He was asked "to put back" and not "to throw away". This means that Christians have moral rights to defend themselves against the unjust aggressors.

\section{Implications for Peace}

The advocacy of this paper is that each and every religion in Nigeria enjoys the freedom to exist, thrive and expand. Religious intolerance exists when one religion absolutely stretches its dominance and relevance very elastically up to suppressing others in order to relegate them to extinction even if it means by force. One of the hazardous consequences of absolutism and intolerance, as we see in islamization methods in Nigeria, is that peace is compromised. When peace is a scarce commodity as it is in the country, there is no human progress and human progress is linked intimately with sustainability.

Nigeria is a secular state. This means that the government should not show favoritism to any religion and neither should it make her citizens irreligious. The two powers of politics characterized by temporality and that of religion whose feature is soteriologically eternal should not be married in such a manner that there is an Islamic theocracy. Under this situation, peace suffers and dies and Nigerians, as a consequence, opt for separation along ethnic nationalities and religious affiliations. This explains some aspects of our national crises today.

Peace does not just mean "absence of war". Unfortunately, in Nigeria, there is even war which affects adversely the richest meaning of peace which is the removal of those unjust structures that dehumanize the human person, thereby assisting him/her to reach self-actualization and advance positively the ecological realities around him/her. In Nigeria, one can vividly see a correlation between Islamization and hunger, disease, retrogression, abuse of human rights, loss of freedom and illiteracy which are negative peace values.

The three religions in Nigeria have some links, fundamentally, with peace. Islam is understood to mean peace. The founder of Christian religion, Jesus Christ is Prince of Peace (Isaiah 9:6, Ephesians 2:14), who asks his followers not only to be peaceful but to give peace as he himself gave them peace when he said in John 14:27 Pacem mean do vobis (the peace I give to you). The African Traditional Religion in its worldview celebrates peace - peace with the self, peace in the world, and peace with the gods. So in African Traditional Religion, peace has religious significance. It is called Udo in Igbo, Emem in Ibibio/Efik, Khuerhe in Edo or toro, tooro in Yoruba, Ebo in Idoma and so on. In Igbo culture, the palm frond is a symbol of peace when tied to the body or carried in the mouth or pegged in a disputed piece of land. The Aafia or Aalafia used in Nigeria in Yoruba or Hausa-Fulani language as peace is from the Arabic al afya which means health, grace, pardon or mercy. Sins and transgressions violate the peace of the land in traditional African Societies such as the Igbo land. Murder, incest, adultery, stealing, and suicide are examples of such transgressions. In order to restore peace, there must be a ritual to the gods. One sees why 
terrorism for any reason is abhorred in typical Igbo society and in many, if not all, African traditional societies (Ele, 2017).

With the present Islamisation methods, peace cannot thrive in Nigeria. This is because social justice that preaches equity, human dignity and sustainable peace and social development are violated grossly. Human beings have the inalienable rights such as the right to life, free associations and freedom of worship. In as much as some Muslims want to take the soul of the Nigerian religious space by these Islamisation methods in order to advance their fake sense of superiority complex, control the political domain and increase their economic affluence, peace is implicated negatively. Islam means peace. Islamization method today says "if you want peace, prepare for war" (si vis Pacem, parabellum). No, this is wrong. What they should do is to prepare for justice. Hence, "if you want peace, prepare for justice" (si vis Pacem, para iustitiam).

\section{Recommendations}

In order to ensure the peaceful co-existence of all religions in Nigeria, these recommendations are made:

1. Nigerians should learn to live in peace which has eluded them through religious bigotry.

2. Religion should not occupy our political space as a tool to achieving political governance.

3. Religion should not be by force, it should be by choice.

4. Let each Religion respect the values found in others so that there could be a meaningful dialogue among her adherents.

5. Religion should be given some chance to develop Nigeria as it has integrative forces and powers of social transformation when it is not manipulated for selfish objectives.

6. Religious leaders should eschew exclusivity and engage themselves and their followers in peacebuilding.

7. Let religions develop partnerships with each other in order to work for social progress and human development.

8. Nigerian constitution has to be amended in order to become truly an unbiased base for secularity.

9. Islamic terrorists should face the full wrath of the law.

10. Let Muslims work for peace through justice.

11. Nigeria should close her borders against Islamic migrants and Fulani herdsmen/militia who illegally migrate into the country.

\section{Conclusion}

Peace is a scarce commodity in Nigeria and some critical aspects of this situation are caused by religion. Religion has dual capacities of opposites, both of conflict generations and of conflict resolutions. In other words, religion is neutral and its neutrality is waiting to be prejudiced. However, the historic religious conflicts in Nigeria does not diminish the powers which religion has to contribute to the actualization of sustainable peace in the country.

Today at the forefront of religious terrorism globally is Islam. Islamic terrorists or Jihadists have, unfortunately, the exclusive approach which tends to kill whoever is not a Muslim. Every non-muslim is perceived as an infidel. They cite the noble Qur'an either by proper interpretation or perhaps, by conscious misinterpretation of the following verses to justify their action: Qur'an 2:191, 3:28, 3:85, 5:33, 8:12, 8:60, 8:65, 9:5, 9:30, 9:123, 22:19, 47:4. Islam is a religion of peace but her aggressive or violent jihadists and terrorists are re-writing this understanding through Islamization agenda whose programs include to intimidate, kill, maim and destroy.

Christians following the Divines missionary mandate (Mt 28: 19-20, Mk. 16:15, Acts 1:8) should as well fashion their agenda for Christianization of Nigeria as practitioners of African traditional religion strive too to traditionalreligionize Nigeria as this act of getting new followership is not an exclusivity of Islam. However, the conversion should be by persuasion and choice and not by coercion and force. If the Muslims must dip both the Koran and the sword into the Atlantic Ocean, let every method in the agenda compromise neither the dignity of the human person nor of sustainable peace.

\section{References}

Banu az-Zubair, M.K., n.d. Social justice and resource control in Nigeria: A crisis of legistimacy. Retrieved from http://www.gamji.com/article4000/NEWS4802.htm [Accessed 22/7/17].

Catholic Bishops Conference of Nigeria CBCN, 2001. A communiqué: Towards a just and peaceful society. Lagos.

Damilolly, 2014. Islamization of Nigeria. The Nigerian constitution recognizes only islam in Nairaland forum. Retrieved from http://www.nairaland.com/1839184/islamization-nigeria-nigerian-cons [Accessed 3/2/2018].

Ele, C., 2001. Islamic triumphalism: A threat to christian presence in Nigeria. Shepherd Magazine, 1(2).

Ele, C., 2015. Religious pluralism and sustainable development. Proceedings of International Conference on Harnessing Diversity for Sustainable Development, University of Nigeria, Nsukka, Faculty of the Social Sciences, 21-22 October.

Ele, C.O., 2017. Issues in religion and global peace: An overview in the IMT. International Journal of the Arts and Sciences, 2(2). Retrieved from www.imtijotas.org.ng.

Eyoboka, S. and D. Akinrefon, 2017. Islamization: Nigeria on throes of jihad, christian elders insist in Vanguard. Retrieved from https:www.vanguardngr.com 2017/09/islamization-Nigeria-throes-ji [Accessed 3/2/2018].

Eze, M., 2001. Sharia and the Arab hipocricy. Leader Newspaper, XLIII(18).

Isiguzo, C., 2016. Nwbueze: Islamization Agenda is Real, says Herdman's Menance Part of Plot. Retrieved from https://www.thisdaylive.com/ [Accessed 2/3/2018].

Jannah, C., 2018. Catholic bishops speak on proposed cattle colonies. Daily Post Nigeria. Retrieved from dailypost.ng [Accessed 6/2/18].

Nnanna, O., 2016. Buhari, keep Nigeria off ISMAT! Retrieved from vanguardngr.com [Accessed 3/2/2018].

Onotu, J.J., 1988. Christian muslim relationship in Nigeria muslim master plan. Anim Seminar Paper (Ed), Ben Clima: Onitsha.

Osibanjo, Y., 2017. Osibanjo blasts Christian leaders; reacts to 'Plan' to islamize Nigeria. Islamization Agenda of Nigeria. Retrieved from http://www.izobofolo.com.ng/tay/islamization-agenda-of-niger [Accessed 3/2/2018].

Premium Times, 2016. Editorial, why Buhari should not join the Saudi-Arabia islamic military Alliance. Retrieved from https:www.premiumtimesng.com [Accessed 3/2/2018]. 


\section{Bibliography}

hopefornigeriaonline.com, 2017. The islamization agenda for Nigeria. It's real, already planned out and about to be implemented. Retrieved from http:www.hopefornigeriaonline.com/the-islamisat... [Accessed 3/2/2018].

The Jerusalem Bible Standard Edition, 2013. New Delhi: Alborione Good News Centre

The Noble Quran.

Citation | Christian O. Ele (2018). Islamization of Nigeria: Implications for Sustainable Peace. International Journal of Social Sciences and English Literature, 2: 13-19.

History:

Received: 6 June 2018

Revised: 9 July 2018

Accepted: 6 August 2018

Published: 15 August 2018

Licensed: This work is licensed under a Creative Commons

Attribution 3.0 License (cc) E E

Publisher: Eastern Centre of Science and Education

Eastern Centre of Science and Education is not responsible or answerable for any loss, damage or liability, etc. caused in relation to/arising out of the use of the content. Any queries should be directed to the corresponding author of the article.
Funding: This study received no specific financial support.

Competing Interests: The author declares that there are no conflicts of interests regarding the publication of this paper.

Transparency: The author confirms that the manuscript is an honest, accurate, and transparent account of the study was reported; that no vital features of the study have been omitted; and that any discrepancies from the study as planned have been explained.

Ethical: This study follows all ethical practices during writing. 